\title{
UPAYA MEMACU PERTUMBUHAN TUNAS MIKRO KENTANG KULTIVAR GRANOLA DENGAN JENIS DAN KONSENTRASI SITOKININ BERBEDA
}

\author{
Adinda Rn Pratama, SugiYono, Lucky Prayoga, Ali HuSni
}

Fakultas Biologi, Universitas Jenderal Soedirman, Jalan dr. Suparno 63 Purwokerto 53122

\section{A B S T R A C T}

Micro-shoot growth is the first step in the potato microtuber formation. The main factors were known controlling microtuber formation including the media type, the concentration of sucrose, the type and concentration of plant growth regulators, temperature, and photoperiodicity. This research aimed to determine the influence of the t of cytokinin and its concentration on the micro-shoot formation of Granola cultivar of potato (Solanum tuberosum L.), as well as to determine the best cytokinin type and its concentration on micro-shoot formation of Granola cultivar potato (Solanum tuberosum L.). The research was experimental in a split-plot design. The main plot was the type of cytokinin (BAP and Kinetin), and the subplot was cytokinin concentration at five levels of concentrations, i.e., 0, 5, 10, 15 and 20 $\mu \mathrm{M}$. This study replicated each treatment three times which resulted in obtaining 30 experimental units. The da ta obtained were then analyzed using an analysis of variance, followed by honest significant difference test at 95 and $99 \%$ levels of confidence. The results showed that the formation of micro-shoot of Granola cultivar of potato was controlled by the type and concentration of cytokinin used. The addition of $5-15 \mu \mathrm{M}$ of BAP was found to be the best treatments to stimulate micro-shoot formation of Granola cultivar of potato.

KEY WORDS: Potato, Granola Cultivar, Microtuber, Microshoot, BAP, Kinetin

Penulis korespondensi: SUGIYono | email: gieks_sugiyono@hotmail.com

\section{PEND A H UL U A N}

Tanaman kentang (Solanum tuberosum Linn.) merupakan salah satu pilihan tanaman holtikultura potensial karena umbi kentang merupakan sumber protein, lemak, karbohidrat, besi dan vitamin (B1, B2, Niacin dan Vitamin C) (Kusumo \& Adiyoga dalam Asandi \& Gunadi (1989). Kentang mampu memproduksi protein lebih banyak dibandingkan gandum dan beras (Thurton, 2001). Tanaman Kentang merupakan tanaman penting dunia, termasuk Indonesia karena merupakan sumber makanan terbesar keempat di dunia setelah padi, gandum dan jagung (Wattimena, 2000), bernilai ekonomi tinggi (Gunarto, 2007; Rusiman, 2008), dan merupakan salah satu jenis tanaman sayuran komoditi andalan sektor pertanian di dataran tinggi yang mendapat perioritas dikembangkan (Direktorat Bina Perlindungan Tanaman, 1994).

Kendala yang dihadapi dalam peningkatan produksi kentang menurut Wattimena et al., (1992) dan Rukmana (1997) adalah: 1) belum tersedia kultivar standar yang sesuai dengan lingkungan tumbuh dan kebutuhan pasar; 2) belum ada pengusaha/petani bibit kentang bermutu sehingga masih diimpor dari Belanda, Belgia dan Jerman; 3) adanya beberapa penyakit yang belum dapat/sukar dikendalikan; 4) belum tersedianya teknik budidaya yang tepat untuk menjamin produksi dan kelestarian lahan usaha; 5) belum tersedianya teknologi pasca panen yang dapat memperpanjang masa simpan serta menjamin kualitas hasil; dan 6) lahan pertanaman semakin menyempit. Kultivar impor yang bertahan cukup lama dan saat ini banyak dibudidayakan adalah kultivar Granola, disamping kultivar baru yang diintroduksi khusus untuk kentang olahan, seperti Atlantik \& Bientje (Wattimena et al., 1992).
Umumnya, 85-90\% area pertanaman kentang di Indonesia ditanami varietas kentang Granola yang memiliki keunggulan umur panen pendek, hasil tinggi, bentuk umbi yang baik dan tahan penyakit virus daun menggulung (PLRV) dan virus X atau PVX (Asandhi, 1996; Uijtewall, 1987) serta penyakit busuk daun Phytophthora infestans. Ciri kentang ini adalah kulit dan daging umbi berwarna kuning, umbi oval, dan mata umbi dangkal (Ummah \& Purwito, 2009). Hasil penelitian Balai Penelitian Tanaman Sayuran Lembang, menunjukkan umbi kentang Granola cocok sebagai bahan konsumsi rumah tangga dengan kadar gula \pm 0,043-0,174\% (Rukmana, 1997). Kelemahan kultivar ini adalah tingginya kadar air umbi dan tidak cocok untuk kentang olahan (Uijtewall, 1987).

Ketersediaan bibit kentang bermutu sangat terbatas dikarenakan perbanyakannya sangat lambat dan adanya penyakit yang menyerang bibit sehingga menurunkan hasil panen (Vander Zag \& Wei, 1991). Akibatnya, pemenuhan kebutuhan bibit kentang terpaksa dilakukan dengan memakai bibit lokal yang kurang bermutu (Wattimena et al., 1992), dan karena telah ditanam beberapa generasi infeksi virus semakin menumpuk di dalam umbi bibit (Soelarso, 1997). Salah satu upaya yang dapat dilakukan untuk memperoleh benih kentang bermutu yang bebas virus serta patogen lainnya adalah melalui teknik kultur in vitro (mikropropagasi) (Mellor \& Stace-Smith, 1987; Bostan \& Demirct, 2004). Mikropropagasi kentang dapat melalui stek mikro atau umbi mikro.

Penggunaan umbi mikro sebagai salah satu propagul kentang memiliki beberapa keuntungan antara lain: propagul umbi mikro berasal dari eksplan bebas penyakit akan menghasilkan umbi mikro yang bebas penyakit, umbi mikro akan menghasilkan tanaman yang seragam dan umur panen sama dengan 
umbi biasa, kebutuhan umbi mikro hanya $4-5 \mathrm{~kg} / \mathrm{Ha}$ dibandingkan dengan umbi biasa yang memerlukan 1-2 ton bibit/Ha, mudah dalam penyimpanan, transportasi dan pengiriman, mudah memenuhi persyaratan karantina untuk lalu lintas propagul baik di dalam atau luar negeri (Wattimena, 2006 dalam Muh. Ansyar, et al., 2009).

Faktor utama yang paling menentukan pembentukan umbi mikro kentang adalah jenis media, konsentrasi sukrosa, jenis dan konsentrasi zat pengatur tumbuh, serta suhu dan fotoperiodisitas. Induksi umbi mikro dapat dilakukan pada media MS (Garner and Blake, 1989; Rafique et al., 2004; Fatima et al., 2005; Uranbey, 2005; El-Sawy et al., 2007; Badoni and Chauhan, 2010; Hoque, 2010; Alix et al., 2001; Moeini et al, 2011), dengan panjang penyinaran 10-16 jam (Gopal et al., 1998; Moeini et al, 2011), dan suhu inkubasi cukup rendah $\left(18-25^{\circ} \pm 2^{\circ} \mathrm{C}\right)$, (Gopal et al., 1998; Uranbey et al., 2004; Moeini et al, 2011). Beberapa penelitian menunjukkan bahwa sukrosa merupakan stimulus yang paling penting untuk menginduksi umbi mikro (El-Sawy et al., 2007; Nistor et al., 2010). Konsentrasi sukrosa yang digunakan bervariasi antara 6-12\%. (Garner and Blake, 1989; Alix et al., 2001; Piao et al., 2003; Rafique, 2004; Fatima et al., 2005; 2006; El-Sawy et al., 2007; Altindal and Karadogan, 2010; Aryakia and Hamidoghli, 2010; Hoque, 2010; dan Imani et al., 2010)

Pertumbuhan tunas aksiler merupakan awal pembentukan umbi mikro, karena tunas tersebut memiliki potensi untuk berkembang menjadi stolon dan umbi mikro jika kondisinya sesuai untuk pembentukan umbi. Perkembangan tunas dalam kultur in vitro sangat dipengaruhi oleh jenis dan konsentrasi sitokinin yang ditambahkan ke dalam media tanam. Jenis sitokinin yang biasa digunakan untuk merangsang pertumbuhan dan perkembangan tunas di dalam kultur in vitro, diantaranya kinetin, 2iP, PBA, dan benzyladenine (BA atau BAP) (Pierik, 1987). BAP dan kinetin banyak digunakan digunakan pada kultur karena: 1) aktif pada konsentrasi rendah; 2) relatif stabil pada larutan encer; 3) mudah diserap; dan 4) mudah dimetabolismekan (Heylen et al., 1991; Bertell dan Eliasson, 1992). BAP digunakan pada konsentrasi antara 10-15 mg/l (Zakaria et al., 2008; Badoni and Chauhan, 2010; Imani et al., 2010), sementara kinetin digunakan pada konsentrasi antara $4-15 \mathrm{mg} / \mathrm{L}$.

Mengingat pentingnya pertumbuhan tunas pada pembentukan umbi mikro, maka tujuan penelitian ini adalah untuk mempelajari pengaruh jenis dan konsentrasi sitokinin serta menentukan jenis dan konsentrasi sitokinin yang paling baik untuk memacu pertumbuhan tunas mikro kentang kultivar granola.

\section{MET ODE}

Bahan-bahan yang digunakan dalam penelitia diantaranya tunas $\mathrm{G}_{0}$ (benih sumber generasi vegetatif ke-0 atau Breeder Seed) kentang kultivar Granola yang diperoleh dari Kebun Bibit Hortikultura Kledung, media Murashige dan Skoog-
1962 (MS-1962), sakarosa, agar, Fe-EDTA, Sterile Destilled Water (SDW), akuades, NaOH I N, HCl 1 N, EtOH 70\% dan $96 \%, \mathrm{HgCl}_{2} \quad 0,2 \%$, zat pengatur tumbuh 6-Benzyl Aminopurine (BAP) dan Kinetin. Alat-alat yang digunakan dalam penelitian antara lain cawan petri, timbangan analitik, botol kultur, beaker glass, gelas ukur, botol duran, Erlenmeyer, hot plate magnetic stirrer, $\mathrm{pH}$ meter, pipet, alumunium foil, kertas saring, autoklaf, laminar air flowcabinet (LAF), bunsen, refrigerator, rak kultur, pinset, skalpel, plastik tahan panas (PP), karet, kertas label, sarung tangan, masker dan sprayer.

Penelitian menggunakan metode eksperimental dengan rancangan petak terpisah (split plot design). Jenis Sitokinin (J) (BAP dan Kinetin) sebagai petak utama, dan konsentrasi (K) sebagai anak petak yang terdiri atas 5 taraf $(0,5,10,15$ dan $20 \mu \mathrm{M}$ ). Masing-masing perlakuan diulang 3 kali sehingga diperoleh 30 unit percobaan.

Variabel yang diamati adalah pertumbuhan tunas mikro kentang kultivar granola. Parameter yang diukur meliputi: waktu muncul tunas (hari), jumlah tunas (buah), rataan panjang tunas $(\mathrm{Cm})$, waktu muncul akar (hari), jumlah akar (buah), dan rataan panjang akar $(\mathrm{Cm})$. Jenis data yang digunakan adalah data empirik dan dianalisis dengan analisis ragam (ANOVA), dilanjutkan dengan uji BNJ dengan tingkat kepercayaan 95 dan 99\%, jika terdapat pengaruh perlakuan.

Eksplan yang digunakan adalah kultur tunas $\mathrm{G}_{0}$ (generasi vegetatif ke-0 atau Breeder Seed) kentang kultivar granola yang diperoleh dari Kebun Bibit Hortikultura Kledung. Eksplan yang ditanam berupa potongan dua ruas (double node culture) dan dinokulasikan ke media MS $(1962)+$ sukrosa $8 \%$ dengan volume masing-masing \pm 33 $\mathrm{mL}$ sesuai perlakuan secara aseptis. Masing-masing botol ditanami 2 eksplan. Botol kultur kemudian ditutup dengan rapat menggunakan plastic dan diikat dengan karet diberi label keterangan jenis perlakuan dan tanggal dilakukan inokulasi. Eksplan diinkubasi dalam keadaan terang (continuous light) pada suhu $24^{\circ} \mathrm{C}$ di rak kultur.

\begin{tabular}{lcccc}
\hline Petak utama & Anak petak & \multicolumn{3}{c}{ Ulangan } \\
\cline { 3 - 5 } (K) & $\mathrm{K}_{0}: 0 \mu \mathrm{M}$ & I & II & III \\
\hline & $\mathrm{J}_{1}: 5 \mu \mathrm{K} \mathrm{K}_{0} \mathrm{U}_{1}$ & $\mathrm{~J}_{1} \mathrm{~K}_{0} \mathrm{U}_{2}$ & $\mathrm{~J}_{1} \mathrm{~K}_{0} \mathrm{U}_{3}$ \\
& $\mathrm{~J}_{1} \mathrm{~K}_{1} \mathrm{U}_{1}$ & $\mathrm{~J}_{1} \mathrm{~K}_{1} \mathrm{U}_{2}$ & $\mathrm{~J}_{1} \mathrm{~K}_{1} \mathrm{U}_{3}$ \\
$\mathrm{~J}_{1}:$ BAP & $\mathrm{K}_{2}: 10 \mu \mathrm{M}$ & $\mathrm{J}_{1} \mathrm{~K}_{2} \mathrm{U}_{1}$ & $\mathrm{~J}_{1} \mathrm{~K}_{2} \mathrm{U}_{2}$ & $\mathrm{~J}_{1} \mathrm{~K}_{2} \mathrm{U}_{3}$ \\
& $\mathrm{~K}_{3}: 15 \mu \mathrm{M}$ & $\mathrm{J}_{1} \mathrm{~K}_{3} \mathrm{U}_{1}$ & $\mathrm{~J}_{1} \mathrm{~K}_{3} \mathrm{U}_{2}$ & $\mathrm{~J}_{1} \mathrm{~K}_{3} \mathrm{U}_{3}$ \\
& $\mathrm{~K}_{4}: 20 \mu \mathrm{M}$ & $\mathrm{J}_{1} \mathrm{~K}_{4} \mathrm{U}_{1}$ & $\mathrm{~J}_{1} \mathrm{~K}_{4} \mathrm{U}_{2}$ & $\mathrm{~J}_{1} \mathrm{~K}_{4} \mathrm{U}_{3}$ \\
\hline \multirow{5}{*}{$\mathrm{J}_{2}:$ Kinetin } & $\mathrm{K}_{0}: 0 \mu \mathrm{M}$ & $\mathrm{J}_{2} \mathrm{~K}_{0} \mathrm{U}_{1}$ & $\mathrm{~J}_{2} \mathrm{~K}_{0} \mathrm{U}_{2}$ & $\mathrm{~J}_{2} \mathrm{~K}_{0} \mathrm{U}_{3}$ \\
& $\mathrm{~K}_{1}: 5 \mu \mathrm{M}$ & $\mathrm{J}_{2} \mathrm{~K}_{1} \mathrm{U}_{1}$ & $\mathrm{~J}_{2} \mathrm{~K}_{1} \mathrm{U}_{2}$ & $\mathrm{~J}_{2} \mathrm{~K}_{1} \mathrm{U}_{3}$ \\
& $\mathrm{~K}_{2}: 10 \mu \mathrm{M}$ & $\mathrm{J}_{2} \mathrm{~K}_{2} \mathrm{U}_{1}$ & $\mathrm{~J}_{2} \mathrm{~K}_{2} \mathrm{U}_{2}$ & $\mathrm{~J}_{2} \mathrm{~K}_{2} \mathrm{U}_{3}$ \\
& $\mathrm{~K}_{3}: 15 \mu \mathrm{M}$ & $\mathrm{J}_{2} \mathrm{~K}_{3} \mathrm{U}_{1}$ & $\mathrm{~J}_{2} \mathrm{~K}_{3} \mathrm{U}_{2}$ & $\mathrm{~J}_{2} \mathrm{~K}_{3} \mathrm{U}_{3}$ \\
& $\mathrm{~K}_{4}: 20 \mu \mathrm{M}$ & $\mathrm{J}_{2} \mathrm{~K}_{4} \mathrm{U}_{1}$ & $\mathrm{~J}_{2} \mathrm{~K}_{4} \mathrm{U}_{2}$ & $\mathrm{~J}_{2} \mathrm{~K}_{4} \mathrm{U}_{3}$ \\
\hline
\end{tabular}

\section{HASIL DAN PEMBAHASAN}

Eksplan yang ditanam selama 8 minggu pada media perlakuan sebagian besar mampu membentuk tunas mikro dan akar yang merupakan tahap pertama untuk menghasilkan umbi mikro. Induksi tunas mikro kentang merupakan salah satu cara mendapatkan meristem tanaman dalam jumlah banyak. Tahap pembentukan tunas mikro (Gambar 1) muncul diantara tangkai daun dan batang dengan jumlah lebih dari satu, berukuran kecil. Menurut Roca et al., (1978) dalam Kusumaningrum (2007), eksplan berupa meristem dan tunas pucuk kentang sering digunakan karena memiliki kestabilan genetik tinggi. 


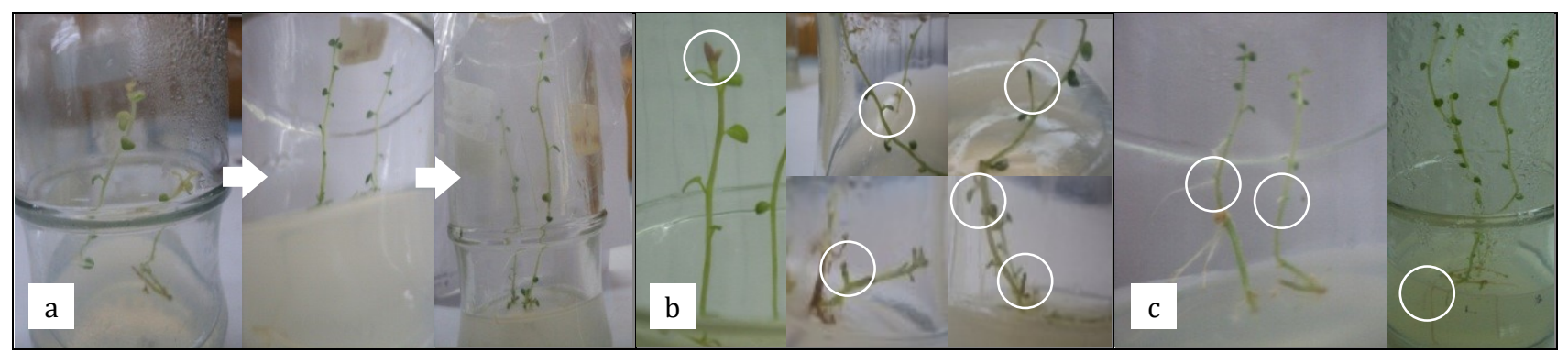

Gambar 1. Tahap pembentukan tunas pada eksplan kentang kultivar granola: a. pemanjangan pucuk; b. pembentukan dan pemanjangan tunas; dan c. pembentukan dan pemanjangan akar (Zulkarnain, 2009).

Waktu kemunculan tunas (Gambar 2), paling cepat pada hari ke-15 setelah tanam dari perlakuan media $\mathrm{J}_{2} \mathrm{~K}_{2}$ (kinetin $10 \mu \mathrm{M}$ ) dan paling lambat dari perlakuan $\mathrm{J}_{1} \mathrm{~K}_{4}$ (BAP $\left.20 \mu \mathrm{M}\right)$ pada hari ke-36. Hasil analisis varian, menunjukkan jenis dan konsentrasi zat pengatur tumbuh pada media kultur tidak berpengaruh nyata terhadap waktu muncul tunas plantlet kentang kultivar granola. Fakta ini mengindikasikan bahwa untuk inisiasi tunas dari eksplan yang berasal dari kultur in vitro tidak diperlukan penambahan zat pengatur tumbuh eksogen. Hal tersebut diduga karena tingginya konsentrasi zat pengatur tumbuh endogen di dalam ekplan yang digunakan. Eksplan yang digunakan berasal dari hasil kultur dalam media yang mengandung sitokinin (BAP). BAP adalah zat pengatur tumbuh yang mudah diserap dan ditranslokasikan dalam bentuk 9R-BAP (9, $\beta$-DRibofuranosyl-BAP) dan disimpan dalam bentuk 3GBAP (3, $\beta$-D-Glukopyranosyl-BAP) dan 9 G-BAP $(9, \beta-$ D-Glukopyranosyl-BAP). Bentuk BAP simpanan ini mudah terhidrolisis dan membebaskan BAP aktif oleh enzim $\beta$-Glukosidase (Blakesley, et al 1991 dalam Sugiyono, 1993).

Hasil penghitungan jumlah tunas (Gambar 3), tunas terbanyak diperoleh dari perlakuan $\mathrm{J}_{1} \mathrm{~K}_{1}$ (BAP 5 $\mu \mathrm{M}$ ), sedangkan paling sedikit didapat dari perlakuan $\mathrm{J}_{2} \mathrm{~K}_{4}$ (Kinetin $20 \quad \mu \mathrm{M}$ ). Hasil analisis varian menunjukkan jenis dan konsentrasi sitokinin sangat mempengaruhi jumlah tunas pada kentang kultivar granola yang terbentuk.

Hasil uji BNJ menunjukkan, sitokinin jenis BAP lebih baik dibandingkan dengan Kinetin. BAP merupakan zat pengatur tumbuh yang sangat aktif, stabil pada larutan encer, sangat mudah diserap, mudah ditranslokasikan, mudah disimpan, mudah dimetabolismekan dan sangat aktif meskipun pada konsentrasi yang rendah. Pemberian sitokinin $0-15$ $\mu \mathrm{M}$ mampu menghasilkan jumlah tunas yang lebih banyak daripada pemberian sitokinin dengan konsentrasi $20 \mu \mathrm{M}$. Hal ini mengindikasikan bahwa pemberian sitokinin $>20 \mu \mathrm{M}$ dapat menghambat pembentukan tunas pada eksplan kentang kultivar Granola. Penambahan sitokinin dapat mendorong inisisasi tunas lateral dan mengurangi dominansi apikal. Selain itu dapat pula merangsang pembelahan sel, pembesaran sel, diferensiasi akar dan tunas (Krishnamoorthy, 1981). Sitokinin jenis BAP merupakan sitokinin yang banyak berperan dalam pembentukan dan penggandaan tunas dan pengaruhnya lebih kuat dibandingkan sitokinin lainnya seperti kinetin ataupun 2-iP (George dan Sherrington, 1984 dalam Zulkarnain, 2009).

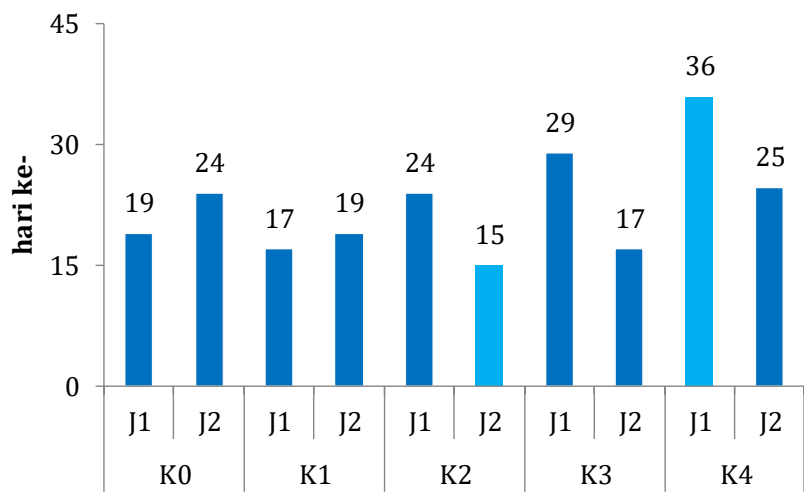

Gambar 2. Histogram Waktu Kemunculan Tunas (hari). Keterangan: J1 : BAP, J2 : Kinetin, K0: $0 \mu \mathrm{M}, \mathrm{K} 1: 5 \mu \mathrm{M}, \mathrm{K} 2: 10 \mu \mathrm{M}, \mathrm{K} 3$ : $15 \mu \mathrm{M}, \mathrm{K} 4: 20 \mu \mathrm{M}$.

Hasil pengukuran rataan panjang tunas (Gambar 4), menunjukkan bahwa rataan tunas terpanjang $(0,40$ $\mathrm{cm}$ ) diperoleh dari perlakuan $\mathrm{J}_{2} \mathrm{~K}_{3}$ (Kinetin $15 \mu \mathrm{M}$ ), sedangkan tunas terpendek $(0,20 \mathrm{~cm})$ dari perlakuan $\mathrm{J}_{1} \mathrm{~K}_{2}(\mathrm{BAP} 10 \mu \mathrm{M}), \mathrm{J}_{1} \mathrm{~K}_{4}\left(\mathrm{BAP} 20 \mu \mathrm{M}\right.$ ) dan $\mathrm{J}_{2} \mathrm{~K}_{4}$ (Kinetin $20 \mu \mathrm{M})$.

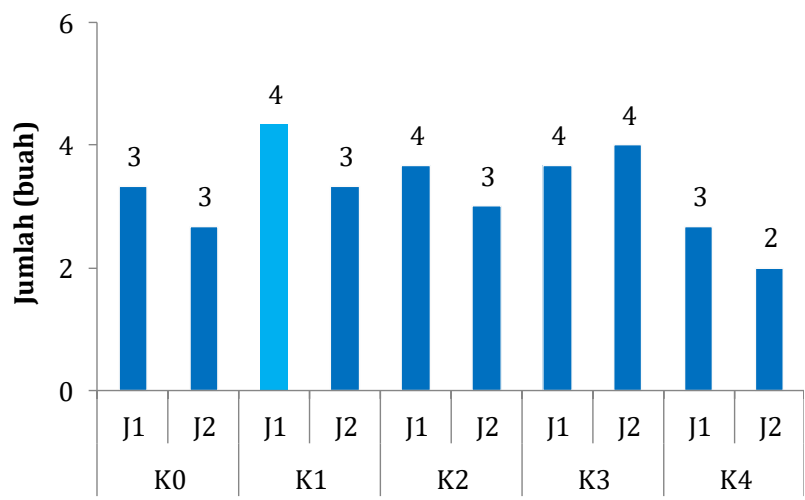

Gambar 3. Histogram Rataan Jumlah Tunas (buah). Keterangan: J1 : BAP, J2 : Kinetin, K0: $0 \mu \mathrm{M}, \mathrm{K} 1: 5 \mu \mathrm{M}, \mathrm{K} 2: 10 \mu \mathrm{M}, \mathrm{K} 3$ : $15 \mu \mathrm{M}, \mathrm{K} 4: 20 \mu \mathrm{M}$.

Hasil analisis varian data tersebut, menunjukkan bahwa penambahan konsentrasi zat pengatur tumbuh sitokinin pada media kultur berpengaruh nyata terhadap rataan panjang tunas, sedangkan jenis sitokinin yang diujikan tidak berbeda nyata. Namun demikian, hasil uji BNJ rataan panjang tunas 
menunjukkan bahwa perlakuan konsentrasi tidak memberikan perbedaan yang nyata terhadap panjang tunas yang terbentuk. Hal ini dapat dipahami karena secara umum sitokinin merangsang inisiasi tunas dan tidak mengatur perpanjangan tunas. Manurung, (2007) menyatakan bahwa semakin tinggi konsentrasi sitokinin yang diberikan maka jumlah tunas yang tumbuh semakin banyak tetapi pertumbuhan masing-masing tunas terhambat, karena sitokinin hanya berperan dalam sitokinesis tetapi tidak dapat meningkatkan pertumbuhan organ.

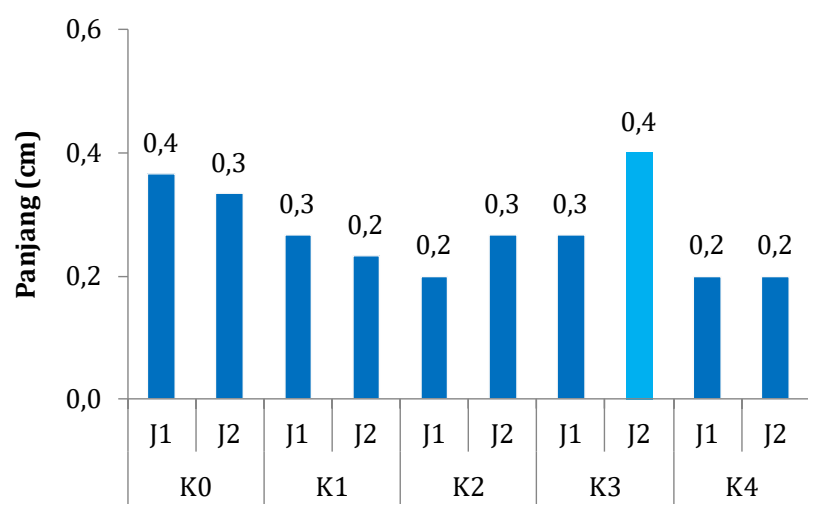

Gambar 4. Histogram Rataan Panjang Tunas $(\mathrm{Cm})$ Keterangan: J1: BAP, J2: Kinetin, K0: $0 \mu \mathrm{M}, \mathrm{K} 1: 5 \mu \mathrm{M}, \mathrm{K} 2: 10 \mu \mathrm{M}, \mathrm{K} 3$ : $15 \mu \mathrm{M}, \mathrm{K} 4: 20 \mu \mathrm{M}$.

Rataan waktu kemunculan akar (Gambar 5), menunjukkan bahwa akar muncul paling cepat pada hari ke-7 (minggu ke-1) dari perlakuan media $\mathrm{J}_{2} \mathrm{~K}_{2}$ dan $\mathrm{J}_{2} \mathrm{~K}_{3}$ (Kinetin 10 dan $15 \mu \mathrm{M}$ ), sedangkan paling lambat muncul akar adalah perlakuan $\mathrm{J}_{2} \mathrm{~K}_{4}$ (Kinetin $20 \mu \mathrm{M}$ ) pada hari ke-28 (minggu ke-4). Hasil analisis varian data tersebut, menunjukkan bahwa penambahan zat pengatur tumbuh jenis sitokinin pada media kultur berpengaruh nyata terhadap waktu kemunculan akar, sedangkan konsentrasi sitokinin yang ditambahkan tidak berbeda nyata. Hasil uji BNJ menunjukkan bahwa sitokinin jenis kinetin menghambat pertumbuhan akar.

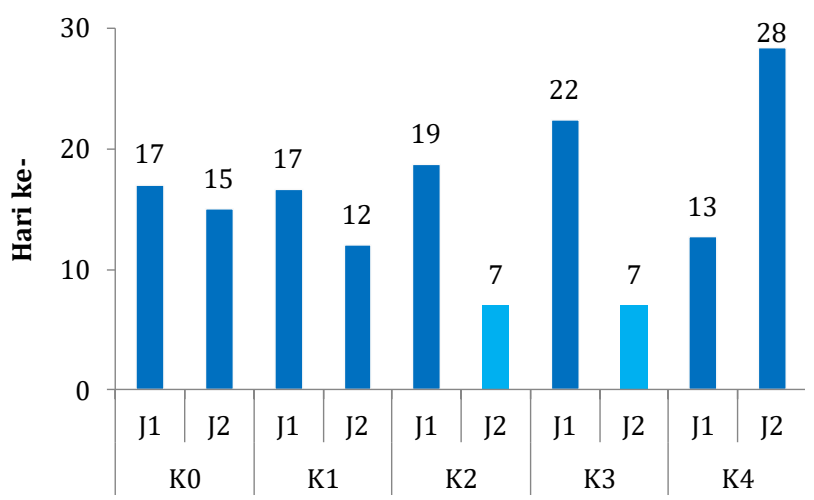

Gambar 5. Histogram Rerata Waktu Muncul Akar (hari). Keterangan: J1 : BAP, J2 : Kinetin, K0: $0 \mu \mathrm{M}, \mathrm{K} 1: 5 \mu \mathrm{M}, \mathrm{K} 2: 10 \mu \mathrm{M}, \mathrm{K} 3$ : $15 \mu \mathrm{M}, \mathrm{K} 4: 20 \mu \mathrm{M}$.

Kemunculan tunas dan akar (Gambar 6) terlihat bahwa pembentukan akar terjadi mendahului pembentukan tunas. Secara umum diketahui bahwa pembentukan tunas akan terhambat ketika akar sudah mulai terbentuk pada eksplan. Sebaliknya, akar akan mudah terbentuk dari tunas yang tumbuh dengan sempurna, karena pembentukan akar dipacu oleh auksin yang disintesis di bagian meristem tunas (Krishnamoorthy, 1981; Pierik, 1987).

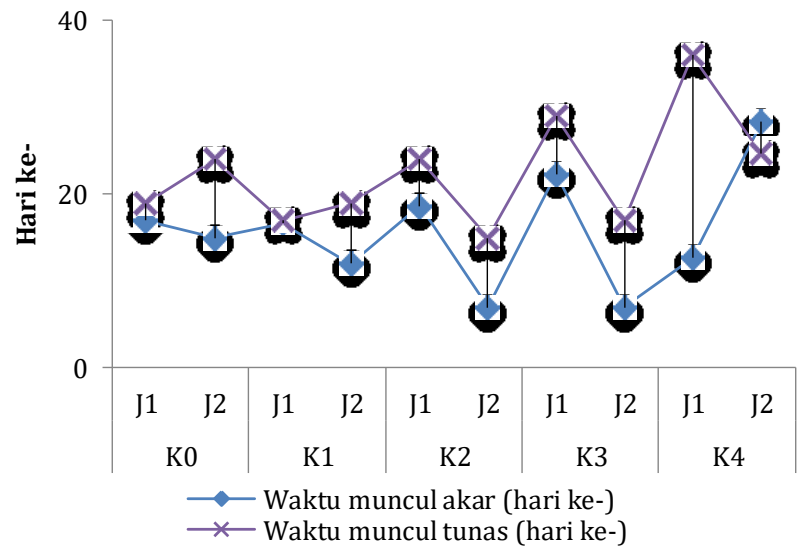

Gambar 6. Grafik Hubungan antara Waktu Kemunculan Tunas dan Akar dengan Konsentrasi Sitokinin pada plantlet kentang kultivar granola. Keterangan: J1 : BAP, J2 : Kinetin, K0: 0 $\mu \mathrm{M}, \mathrm{K} 1: 5 \mu \mathrm{M}, \mathrm{K} 2: 10 \mu \mathrm{M}, \mathrm{K} 3: 15 \mu \mathrm{M}, \mathrm{K} 4: 20 \mu \mathrm{M}$.

Hasil penghitungan rataan jumlah akar (Gambar 7) menunjukkan bahwa rataan jumlah akar terbanyak diperoleh dari perlakuan tanpa sitokinin $\left(\mathrm{J}_{2} \mathrm{~K}_{0}\right.$ dan $\mathrm{J}_{1} \mathrm{~K}_{0}$ ). Menurut Fossard dalam Ambarwati (1987), medium tanpa sitokinin lebih baik daripada medium yang mengandung sitokinin untuk pembentukan akar. Hasil analisis varian waktu muncul akar, menunjukkan bahwa penambahan konsentrasi sitokinin pada medium tanam berbeda sangat nyata terhadap jumlah akar pada plantlet kentang kultivar granola. Selanjutnya, hasil uji BNJ rataan jumlah akar menunjukkan bahwa peningkatan konsentrasi sitokinin menghambat pembentukan akar. Secara umum diketahui bahwa pembentukan akar dihambat oleh tingginya konsentrasi sitokinin di dalam media (Pierik, 1987; Santi \& Kusumo, 1996).

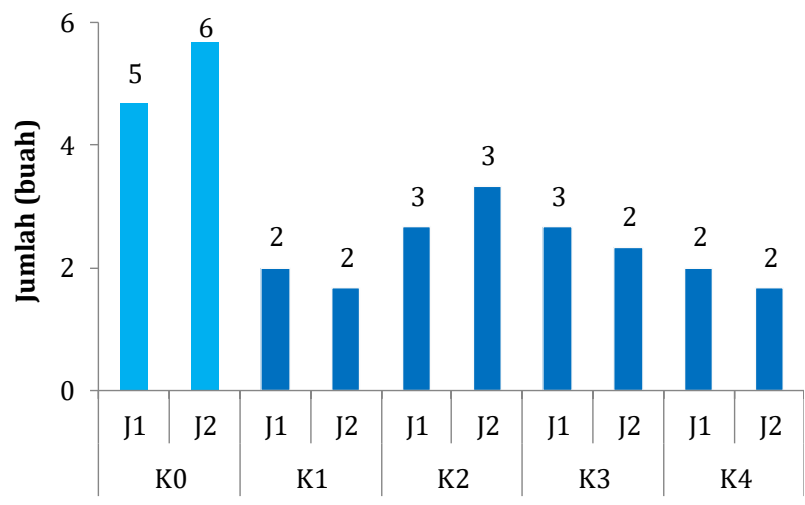

Gambar 7. Histogram Rataan Jumlah Akar (buah). Keterangan: J1 : BAP, J2 : Kinetin, K0: $0 \mu \mathrm{M}, \mathrm{K} 1: 5 \mu \mathrm{M}, \mathrm{K} 2: 10 \mu \mathrm{M}, \mathrm{K} 3$ : $15 \mu \mathrm{M}, \mathrm{K} 4: 20 \mu \mathrm{M}$.

Konsentrasi tinggi zat pengatur tumbuh sitokinin (BAP dan Kinetin) pada media kultur dapat menghambat pembentukan akar. Peningkatan konsentrasi BAP cenderung menekan pertumbuhan akar karena BAP termasuk jenis sitokinin yang dapat menghambat inisiasi dan pertumbuhan akar, 
terutama bila diberikan dalam konsentrasi yang tinggi (Pierik, 1987 dalam Manurung, 2007). Penambahan BAP pada medium tanam (Gambar 8) dapat meningkatkan jumlah tunas dan daun serta mempunyai kecenderungan menurunkan jumlah akar dan tinggi tunas. Hal ini sesuai dengan hasil penelitian Kurniawati, 2004 dalam Manurung, (2007). Diharapkan dengan meningkatnya jumlah tunas/buku maka jumlah umbi mikro akan meningkat (Buchory dan Karjadi, 2007). Jenis dan konsentrasi terbaik untuk mendukung pertumbuhan tunas mikro yang maksimal untuk pembentukan umbi mikro adalah jumlah tunas terbanyak dengan panjang tunas terpendek. Dalam penelitian ini diketahui bahwa penambahan sitokinin jenis BAP dengan konsentrasi 5-15 $\mu \mathrm{M}$.

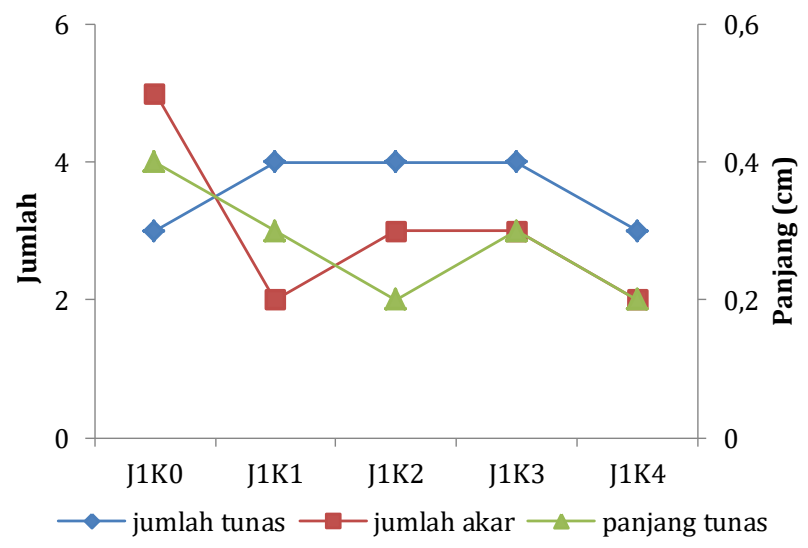

Gambar 8. Grafik hubungan antara jumlah tunas, jumlah akar, dan panjang tunas dengan konsentrasi sitokinin BAP pada plantlet kentang kultivar granola. Keterangan: J1 : BAP, J2 : Kinetin, K0: $0 \mu \mathrm{M}, \mathrm{K} 1: 5 \mu \mathrm{M}, \mathrm{K} 2: 10 \mu \mathrm{M}, \mathrm{K} 3: 15 \mu \mathrm{M}, \mathrm{K} 4: 20 \mu \mathrm{M}$.

Hasil pengukuran panjang akar (Gambar 9), menunjukkan bahwa perlakuan tanpa penambahan sitokinin $\left(\mathrm{J}_{1} \mathrm{~K}_{0}\right.$ dan $\left.\mathrm{J}_{2} \mathrm{~K}_{0}\right)$ merupakan perlakuan terbaik yang mempengaruhi penambahan panjang akar dengan panjang akar terpanjang $(2,1$ dan 2,3 cm), sedangkan rataan panjang akar terpendek $(0,5 \mathrm{~cm})$ dihasilkan dari perlakuan $\mathrm{J}_{1} \mathrm{~K}_{4}$ dan $\mathrm{J}_{2} \mathrm{~K}_{4}$ (BAP dan kinetin $20 \mu \mathrm{M}$ ). Hasil analisis varian data tersebut menunjukkan bahwa konsentrasi sitokinin yang ditambahkan pada media tanam berbeda sangat nyata terhadap pertumbuhan panjang akar. Hasil uji BNJ menunjukkan bahwa peningkatan konsentrasi sitokinin menghambat perpanjangan akar. Hal ini sesuai dengan pernyataan George \& Sherrington (1984), bahwa aktivitas sitokinin dapat menghambat pembentukan akar, menghalangi pertumbuhan akar, dan menghambat pengaruh auksin terhadap inisiasi akar pada kultur jaringan sejumlah spesies tertentu sehingga biasanya tidak digunakan untuk tahap pengakaran pada mikropropagasi.

Penambahan sitokinin dalam konsentrasi yang terlalu tinggi menyebabkan pemendekan ruas-ruas batang, bahkan hampir rapat antara yang satu dengan yang lain, sehingga tanaman menjadi bushy (Gambar 10a). Stek tunas dengan ruas batang yang sangat pendek, sangat sulit untuk ditanam dalam medium pengakaran (Novak et al., 1980). Pada penelitian ini ditemukan pula pembengkakan pada pangkal batang kentang in vitro (Gambar 10b), dan tunas-tunas tumbuh dalam gerombol (cluster).

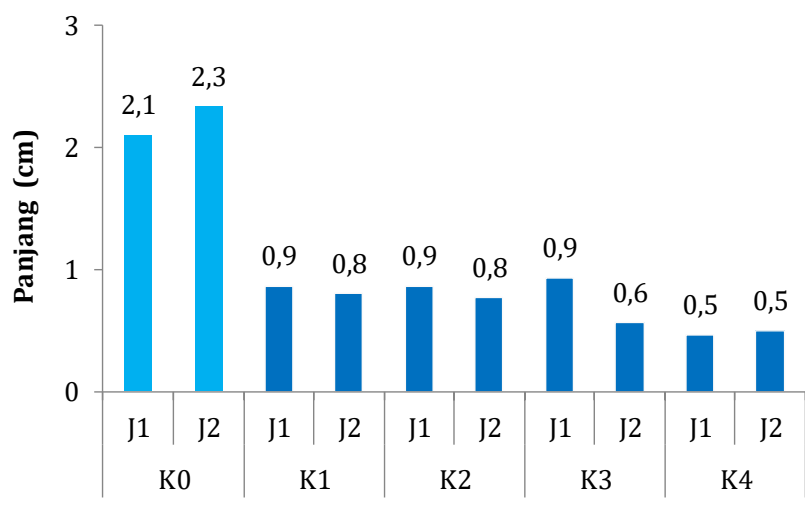

Gambar 9. Histogram Rataan Panjang Akar (Cm). Keterangan: J1 : BAP, J2 : Kinetin, K0: $0 \mu \mathrm{M}, \mathrm{K} 1: 5 \mu \mathrm{M}, \mathrm{K} 2: 10 \mu \mathrm{M}, \mathrm{K} 3$ : $15 \mu \mathrm{M}, \mathrm{K} 4: 20 \mu \mathrm{M}$.

Keadaan yang mirip demikian tampak pada medium yang mengandung kinetin akibat ruas batang yang sangat pendek sehingga tunas-tunas yang tumbuh tampak bergerombol seperti pada penelitian Hussey dan Stacey (1981) yang terjadi pada medium yang mengandung BAP (Zulkarnain, 2009). Dalam penelitian ini ditemukan pula gangguan fisiologis yang terjadi pada kultur in vitro pucuk Solanum tuberosum berupa nekrosis (Gambar 10c), yang merupakan salah satu masalah utama pada kultur in vitro (Sha et.al., (1985) dalam Zulkarnain, (2009). Nekrosis dicirikan oleh matinya jaringan pada tepi daun dan pucuk dengan gejala awal ujung dan tepi daun muda berwarna cokelat pucat, kemudian merata pada keseluruhan meristem dan akhirnya berwarna hitam dan mati (Salisbury \& Ross, 1994).

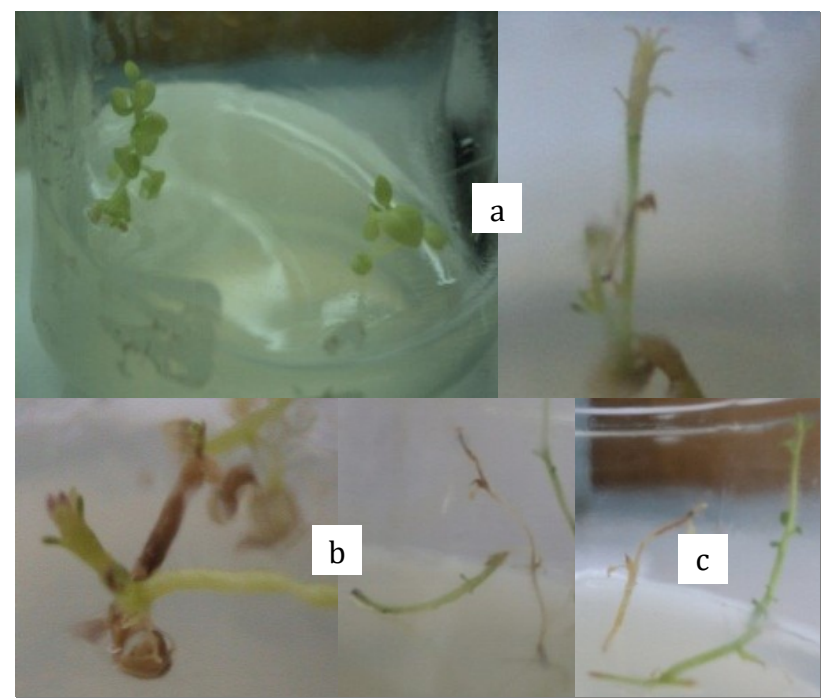

Gambar 10. (a) Ruas-ruas batangyang sangat pendek (bushy) yang ditemukan ketika inkubasi selama 8 minggu; (b) pembengkakan pada pangkal batang kentang in vitro dan tunas-tunas tumbuh dalam gerombol (cluster); dan (c) gangguan fisiologis yang terjadi pada kultur in vitro pucuk Solanum tuberosum berupa Nekrosis. 


\section{KESIMPULAN DAN SARAN}

Jenis dan konsentrasi sitokinin berpengaruh terhadap pertumbuhan tunas kentang kultivar Granola. BAP dengan konsentrasi 5-15 $\mu \mathrm{M}$ merupakan perlakuan terbaik untuk memacu pertumbuhan tunas kentang kultivar Granola. BAP dengan konsentrasi 5-15 $\mu \mathrm{M}$ yang dapat digunakan untuk memacu pembentukan tunas dalam upaya meningkatkan produksi umbi mikro kentang kultivar Granola. Namun demikian perlu penelitian lebih lanjut dengan mengkombinasikan BAP dengan sukrosa sebagai stimulator terpenting pada pembentukan umbi mikro.

\section{DAFT AR REFERENS I}

Alix MJ, Savvides S, Blakef J, Herrmanin R, Horinung R. 2001. Effects of Lumination Source, Culture Ventilation and Sukrosa on Potato (Solanum Tuberosum) Microtuber Production Under Short Days. Ann. Appl. Biol. 139:175-8.

Altindal D, Karadogan T. 2010. The Effect of Carbon Sources on In Vitro Microtuberization of Potato (Solanum Tuberosum L.). Turkish Journal of Field Crops. 15(1):7-11.

Ambarwati AD. 1987. Induksi Kalus dan Differensiasi pada Kultur Jaringan Gnetum gnemon L. Fakultas Biologi Universitas Gadjah Mada. Yogyakarta.

Ansyar M, Ala A, Baharuddin dan Elkawakib S. 2009. Potensi Ekstrak Daun Gamal dan Filtrat Cendawan Diplodia spp. sebagai Penginduksi Umbi Mikro Kentang secara In Vitro. J. Sains \& Teknologi, Vol.9 No.2 : 97-105I SSN 1411-4674

Aryakia E, Hamidoghli Y. 2010. Comparison of kinetin and 6-banzyl amino purine effect on in vitro microtuberization of two cultivars of potato (Solanum tuberosum L.). American-Eurasian J. Agric. \& Environ. Sci. 8(6):710-714.

Asandhi AA. 1996. Tumpangsari kentang pada lahan sawah di dataran medium. J. Hort.6(1):23-8.

Asandhi AA, Gunadi N. 1989. Syarat Tumbuh Tanaman Kentang dalam Asandhi, A.A., S. Sastrosiswojo; Suhardi; Z. Abidin dan Subhan (Eds). Balai Penelitian Holtikultura. Lembang. Hal. 2229.

Badoni A, Chauhan JS. 2010. Potato seed production of cultivar kufri himalini. Invitro. Stem Cell 1(1):7-10.

Bertell G, Eliason L. 1992. Cytokinin Effect on Root Growth and Possible Interaction with Ethylene and Indole-3-acetic Acid. Physiologia Plantarum. The Scandinavian Society for Plant Physiology Copenhagen. 84(2):255-261.

Bostan H, Demirct E. 2004. Obtaining PVX, PVY and PLRV-free micro tuber from Granola and Caspar potato (Solanum tuberosum L.) Cultivars. Pakistan J. of Biological Sci.7(7):1135-1139.

Buchory A, Karjadi AK. 2007. Pengaruh Konsentrasi BAP dan Sumber Karbohidrat Gula terhadap Induksi Umbi Mikro Kentang. Balai Penelitian Tanaman Sayuran. J. Agrivigor 6(3):197-205.

El-Sawy A, Bekheet S, Aly UI. 2007. Morphological and Molecular Characterization of Potato Microtubers Production on Coumarin Inducing Medium. International Journal of Agriculture \& Biology. 9(5):675-680.

Fatima B, Usman M, Ahmad I, Khan IA. 2005. Effect of Explant and Sukrosa on Microtuber Induction in Potato Cultivars. International Journal of Agriculture \& Biology. 7(1):63-66.

Garner N, Blake J. 1989. The Induction and Development of Potato Microtubers In vitroon Media Free of Growth Regulating Substances. Annals of Botany. 63:663-674.

George EF, Sherrington PD. 1984. Plant propagation by tissue culture. Exegetics Ltd. p:39-71

Gopal J, Minocha JL, Dhaliwal HS. 1998. Microtuberization in Potato (Solanum tuberosum L.). Plant Cell Reports. 17:794-798.

Gunarto A. 2007. Prospek Agribisnis Kentang G4 Sertifikat di Kabupaten Sukabumi. Pusat Pengkajian dan Penerapan Teknik Budidaya Pertanian.

Heylen C, Vendrig JC, Onckelen HV. 1991. The Accumulation and Metabolism of Plant Growth Regulator During Organogenesis. Physiologia Plantarnum. 83(4):578-584.
Hoque ME. 2010. In vitro tuberization in potato (Solanum tuberosum L.). Plant Omics Journal. 3(1):7-11.

Hussey G, Stacey NT. 1981. In vitro propagation of potato (Solanunitubevosuni L). Annals of Botany. 48;787-796.

Imani AA, Qhrmanzadeh R, Azimi J, Janpoor J. 2010. The Effect of Various Concentrations of 6-Benzylaminopurine (BAP) and Sukrosa on In Vitro Potato (Solanum Tuberosum L.) Microtuber Iduction. American-Eurasion J. Agric. \& Environ. Sci. 8(4):457-459.

Krishnamoorthy HN. 1981. Plant Growth Substances including Application in Agriculture. Tata McGrawHill Publ. Co. Ltd. New Delhi. 214p.

Kusumaningrum IS. 2007. Evaluasi Pertubuhan In vitro dan Produksi Umbi Mikro Beberapa Klon Kentang (Solanum tuberosum L.) Hasil Persilangan Kultivar Atlantik dan Granola [Skripsi]. Program Studi Hortikultura Fakultas Pertanian Institut Pertanian Bogor.

Manurung LY, Santi. 2007. Pengaruh Auksin (2,4-D) dan Sitokinin (BAP) dalam Kultur in Vitro Buah Makasar (Brucea javanica [L.] Merr.) [Skripsi]. Departemen Konservasi Sumberdaya Hutan dan Ekowisata Fakultas Kehutanan Institut Pertanian Bogor.

Mellor FC, Stace-Smith R. 1987. Virus-free potatoes through meristem culture. Biotechnology in Agriculture and Forestry.Vol.3 Potato. Springer-Verlag Berlin Heidelberg.

Moeini MJ, Armin M, Asgharipour MR, Yazdi SK. 2011. Effects of Different Plant Growth Regulators and Potting Mixes on Micropropagation and Mini-tuberization of Potato Plantlets. Advances in Environmental Biology. 5(4):631-638.

Nistor, A., G. Campeanu, N. Atanasiu, N. Chiru, D. Karácsonyi, 2010 Influence of Genotype on Microtuber Production. Not. Bot. Hort. Agrobot. Cluj 38 (1): 209-212.

Novak, P.J. 1, J. Zadina, V. Horackova and I. Maskora. 1980. The effect of growth regulators on meristem tip development and in vitro multiplication of Solanum tuberosum L. Plants. Potato Res. 23: $155-156$.

Piao, X. C., D. Chakrabarty, E. J. Hahn, K. Y. Paek, 2003. A simple method for mass production of potato microtubers using a bioreactor system. Current Science 84 (8): 1129-1132.

Pierik RL. 1987. IN VITRO CULTURE OF HIGHER PLANTS AS A TOOL IN THE PROPAGATION OF HORTICULTURAL CROPS. InInternational Symposium on Propagation of Ornamental Plants 226. pp.25-40).

Rafique, T., M. J. Jaskani, H. Raza, M. Abbas, 2004. In vitro Studies on Microtuber Induction in Potato. International Journal of Agriculture \& Biology, 06(2): 375-377

Rukmana, 1997. Budidaya Kentang dan Pasca panen. Kanisius, Yogyakarta.

Rusiman. 2008. Potato Plant (Tanaman Kentang). http://www. rusiman.bpdas-pemalijratun.net/ index.php? option=com: tanaman-kentang. Diakses 11 November 2011.

Salisbury FB, Ross CW. 1994. Plant Physiology. Wadsworth Publishing, Belmont.

Santi A, Kusumo S. 1996. Komposisi media tumbuh yang cocok untuk perbanyakan Secara In Vitro Bromelia (Tillandsia punctulata L.). Jurnal Hortikultura.5(5):94-8.

Soelarso, R. B. 1997. Budidaya Kentang Bebas Penyakit. Kanisius. Yogyakarta.

Sugiyono, 1993. Pengaruh Pemberian Hormon 2,4-D dan BAP Terhadap Multiplikasi Kalus Purwoceng (Pimpinella Pruatjan Molkenb.) pada Kultur Aseptis. [Skripsi]. Fakultas Biologi Universitas Jenderal Soedirman.

Thurton, H.D. 2001. Origin, history and importance of the potato in Stevenson, W.R. (eds). Compendium of Potato Disease. 2th ed. The American Phytopathological Soc. New York.

Uijtewall BA. 1987. The Production and Evaluation of Monophodial Potatoes $(2 n=X=12)$ for Breeding Research on Cell and Plant Level. Grafisch Bedrijf Ponsen \& Looijen. Wageningen. P12.

Ummah K, Purwito A. 2009. Budidaya Tanaman Kentang (Solanum tuberosum L.) dengan Aspek Khusus Pembibitan di Hikmah Farm, Pangalengan, Bandung, Jawa Barat. Makalah Seminar. Departemen Agronomi dan Hortikultura Fakultas Pertanian Institut Pertanian Bogor.

Uranbey S. 2005. Comparison of Kinetin and 6-Benzyladenine (BA) on in vitro Microtuberization of Potato under Short Days Conditions. Tarım Bilimleri Dergisi. J. Agric. Sci. 15(1):39-41. 
Uranbey S, Parmaksız İ, Sancak C, Cöçü S, Özcan S. 2004. Temperature and gelling agent effects on in vitro microtuberization of potato (Solanum tuberosum L.). Biotechnology \& Biotechnological Equipment. 18(2):89-94.

Vander Zaag P, Wei H. 1991. Potato (Solanum spp). Apical cutting production and their agronomic potential. Asian Potato J. 20(1):17-22.

Wattimena GA. 2000. Pengembangan Propagul Kentang Bermutu dari Kultivar Kentang Unggul dalam Mendukung Peningkatan Produksi Kentang di Indonesia. Orasi Ilmiah Guru Besar Tetap Ilmu Hortikultura Fakultas Pertanian Institut Pertanian Bogor.
Wattimena GA, Gunawan LW, Mattiik NA, Syamsudin E, Armini NM, Ernawati A. 1992. Perbanyakan Tanaman dalam Bioteknologi Tanaman. PAU Bioteknologi Institut Pertanian Bogor. Dirjen Dikti Dept. P\&K.

Zakaria M, Hossain MM, Mian MAK, Hossain T, Uddin MZ. 2008. In Vitro Tuberization of Potato Influenced by Benzyl Adenine and Chloro Choline Chloride. Bangladesh J. Agril. Res. 33(3):419425.

Zulkarnain. 2009. Kultur Jaringan Tanaman Solusi Perbanyakan Tanaman Budi Daya. PT. Bumi Aksara, Jakarta. 